\title{
Superoxide Generation in Extracts from Isolated Plant Cell Walls Is Regulated by Fungal Signal Molecules
}

\author{
Akinori Kiba, Chizu Miyake, Kazuhiro Toyoda, Yuki Ichinose, Tetsuji Yamada, and Tomonori Shiraishi
}

Laboratory of Plant Pathology and Genetic Engineering, College of Agriculture, Okayama University, Okayama, 700 Japan. Accepted for publication 24 April 1997.

\begin{abstract}
Kiba, A., Miyake, C., Toyoda, K., Ichinose, Y., Yamada, T., and Shiraishi, T. 1997. Superoxide generation in extracts from isolated plant cell walls is regulated by fungal signal molecules. Phytopathology 87:846-852.

Fractions solubilized with $\mathrm{NaCl}$ from cell walls of pea and cowpea plants catalyzed the formation of blue formazan from nitroblue tetrazolium. Because superoxide dismutase decreased formazan production by over $90 \%$, superoxide anion $\left(\mathrm{O}_{2}^{-}\right)$may participate in the formation of formazan in the solubilized cell wall fractions. The formazan formation in the fractions solubilized from pea and cowpea cell walls was markedly reduced by exclusion of $\mathrm{NAD}(\mathrm{P}) \mathrm{H}$, manganese ion, or $p$-coumaric acid from the reaction mixture. The formazan formation was severely inhibited by salicylhydroxamic acid and catalase, but not by imidazole, pyri-

the pea pathogen Mycosphaerella pinodes enhanced the activities of formazan formation nonspecifically in both pea and cowpea fractions. The suppressor preparation from $M$. pinodes inhibited the activity in the pea fraction in the presence or absence of the elicitor. In the cowpea fraction, however, the suppressor did not inhibit the elicitor-enhanced activity, and the suppressor alone stimulated formazan formation. These results indicated that $\mathrm{O}_{2}^{-}$generation in the fractions solubilized from pea and cowpea cell walls seems to be catalyzed by cell wall-bound peroxidase(s) and that the plant cell walls alone are able to respond to the elicitor nonspecifically and to the suppressor in a species-specific manner, suggesting the plant cell walls may play an important role in determination of plant-fungal pathogen specificity.
\end{abstract} dine, quinacrine, and diphenyleneiodonium. An elicitor preparation from
Additional keywords: Pisum sativum, species specificity, Vigna sinensis.
A strict specificity is observed in plant-parasite interactions that results in rejection or acceptance of invading pathogens. A pea pathogen, Mycosphaerella pinodes (Berk. \& Bloxam) Vestergr., secretes in its pycnospore germination fluid a glycopeptide elicitor (29) and glycopeptide suppressor of pea defense responses $(31,37-$ 40). In pea tissues, the elicitor induces defense responses such as the production of phytoalexin $(36,44)$ and an, as yet, unidentified infection-inhibitor (45), and the activation of the pathogenesis-related proteins endochitinase and endo- $\beta$ - 1,3 -glucanase (47). Since the elicitor also induces the defense responses in other plant species $(45,47)$, the action of the elicitor is thought not to be species specific. On the other hand, the action of the suppressor preparation was species specific, since it inhibited these defense responses and induced susceptibility only in host plants of $M$. pinodes $(32,38$, $39,47)$. Thus, the suppressor is thought to be a determinant of hostparasite specificity (32).

The involvement of superoxide anion $\left(\mathrm{O}_{2}^{-}\right)$generation in plant defense was first shown in the interaction between potato and Phytophthora infestans, the cause of potato blight $(12,13)$. Since this initial work, there have been many reports that the production of active oxygen species, particularly hydrogen peroxide $\left(\mathrm{H}_{2} \mathrm{O}_{2}\right)$, hydroxyl radical $(\mathrm{OH} \bullet)$, and $\mathrm{O}_{2}^{-}$, were triggered in cultured plant cells, protoplasts, and tissues by treatment with elicitors or by inoculation with potent pathogens (3). Among these active oxygen species, the possible roles of $\mathrm{H}_{2} \mathrm{O}_{2}$ and $\mathrm{O}_{2}^{-}$have been well demonstrated in plant-pathogen interactions. $\mathrm{H}_{2} \mathrm{O}_{2}$ is thought to be required for lignification of the cell wall $(27,28)$ and for oxidative cross-

Corresponding author: T. Shiraishi

E-mail address: tomoshir@cc.okayama-u.ac.jp

Publication no. P-1997-0527-02R

(C) 1997 The American Phytopathological Society linking of hydroxyproline-rich glycoproteins in the cell wall $(7,8)$. It was also suggested that $\mathrm{H}_{2} \mathrm{O}_{2}$ acted as a signal molecule in salicylic acid-mediated, systemic acquired resistance in tobacco plants (10).

$\mathrm{O}_{2}^{-}$was thought to play an important role in plant defenses not only as a toxicant to pathogens, but also as a signal molecule for active defense. Treatment with hyphal cell wall components of $P$. infestans and inoculation with an incompatible race of $P$. infestans induced $\mathrm{O}_{2}^{-}$generation in potato tubers (14). $\mathrm{O}_{2}^{-}$has been thought to act as a signal molecule to induce the defense response, since superoxide dismutase (SOD), the scavenger of $\mathrm{O}_{2}^{-}$, blocked hypersensitive cell death in potato tubers (12). Recently, it was found that the elicitor preparation from $M$. pinodes also nonspecifically induced $\mathrm{O}_{2}^{-}$generation on the leaf surfaces of pea and cowpea, but the suppressor showed a species-specific effect on the $\mathrm{O}_{2}^{-}$generation (23).

In mammalian cells, a neutrophil NADPH oxidase is responsible for the generation of $\mathrm{O}_{2}^{-}$on the extracellular surface of the plasma membrane via a one-electron reduction of dioxygen (11). In plants, it has also been thought that an $\mathrm{O}_{2}^{-}$-generating NADPH oxidase exists in the plasma membrane $(1,15)$. On the other hand, peroxidase in plasma membranes has also been reported to be responsible for the synthesis of $\mathrm{O}_{2}^{-}(2)$. Another study has pointed out the oxidation of NADH by cell wall-bound peroxidases, resulting in the generation of $\mathrm{O}_{2}^{-} / \mathrm{H}_{2} \mathrm{O}_{2}$ through the complex pathway involving the apoplastic NADH, NAD•, and NAD ${ }^{+}$cycles $(19,20)$.

Our previous report suggested that plant cell walls might play an important role in the recognition of fungal signals and in the determination of host-parasite specificity. We found that a cell wallbound ATPase responded to the elicitor and suppressor preparations from $M$. pinodes. In particular, the response to the suppressor preparation was in a species-specific manner $(24,25)$. Though there are several reports that active oxygen species were produced in plant cell walls, as described above, it has been unclear whether the production of active oxygen species in cell wall fractions is 
directly affected by fungal signal molecules. In this report, therefore, we examined whether $\mathrm{O}_{2}^{-}$is generated in fractions solubilized from pea and cowpea cell walls, and whether the elicitor and suppressor preparations from $M$. pinodes are able to regulate such $\mathrm{O}_{2}^{-}$generation.

\section{MATERIALS AND METHODS}

Chemicals. Tris, diphenyleneiodonium (DPI), NADH, NADPH, quinacrine, paracoumaric acid ( $p$-CA), salicylhydroxamic acid (SHAM), catalase (EC 1.11.1.6), and SOD (EC 1.15.1.1) were purchased from Sigma Chemical Co., St. Louis. Other chemicals were from Wako Pure Chemical Inc., Osaka, Japan.

Plant materials. Seeds of pea (Pisum sativum L. cv. Midoriusui) and cowpea (Vigna sinensis (L.) Savi ex Hassk. cv. Sanjakusasage) were sown in vermiculite in plastic containers. Seedlings were grown at 20 to $24^{\circ} \mathrm{C}$ for 8 days in the dark for isolation of the cell wall fractions.

Preparation of cell wall fractions and solubilization of cell wall-bound proteins. Preparation of the cell wall fractions and solubilization of proteins from cell wall fractions with $0.5 \mathrm{M} \mathrm{NaCl}$ were carried out by the method described previously (25). Purity of cell wall fractions from pea and cowpea seedling was assessed by examining the activity of 11 marker enzymes (25). The activities of 5'-nucleotidase and glucose-6-phosphatase, marker enzymes of the nuclear membrane, were not detectable in fractions solubilized from pea and cowpea cell walls. No activities of fumarase and cytochrome c oxidase, marker enzymes of mitochondria, were detected in these fractions. The activities of ribulose bisphosphate carboxylase, NAD $(\mathrm{P}) \mathrm{H}$ cytochrome c reductase, and glucan synthase I, marker enzymes of chloroplasts; endoplasmic reticulum; and Golgi bodies were also not detectable in these fractions. From the results, it was shown that the fractions solubilized from both plant species were relatively free of contamination by nuclei, chloroplast, Golgi bodies, mitochondria, and endoplasmic reticulum. On the other hand, these fractions included the activities of acid phosphatase, but not alkaline phosphatase and nitrate-sensitive ATPase, indicating that tonoplast had also been excluded from the fractions from pea and cowpea cell walls. The activity of glucan synthase II was not detectable in the cowpea fraction, but the specific activity of this enzyme was $0.4 \mu \mathrm{mol} / \mathrm{mg}$ of protein $/ \mathrm{h}$ in the pea fraction. However, this activity was markedly lower than that in plasma membrane fractions, because the specific activities in plasma membrane fractions from pea and cowpea seedling were 15.16 and $18.95 \mu \mathrm{mol} / \mathrm{mg}$ of protein $/ \mathrm{h}$, respectively. Thus, contamination by plasma membrane of the pea cell wall fraction also seemed to be below $3 \%$ with respect to the activity of glucan synthase II. Concentrations of protein in solubilized cell wall fractions were determined by the method of Bradford (6), with bovine serum albumin (BSA) as the standard. The fractions, which were solubilized from pea and cowpea cell walls, were stored at $-20^{\circ} \mathrm{C}$ until used.

Preparation of the elicitor and suppressor from $M$. pinodes. The elicitor and the suppressor preparations were prepared from pycnospore germination fluid of $M$. pinodes strain OMP-1 (IFO30342, ATCC-42741) by the method of Yoshioka et al. (48). Pycniospores formed on Czapek agar medium were suspended in sterilized distilled water. The suspension was shaken in a shaking flask at 20 to $24^{\circ} \mathrm{C}$ for $20 \mathrm{~h}$, and then it was filtered through a Whatman No. 1 filter parer. The filtrate was separated into low- and highmolecular-weight fractions by passage through a ultrafilter (type PTGC 142-05; Millipore Corp., Bedford, MS). The high-molecularweight fraction (molecular weight $>10,000$ ) was dialyzed against sterilized water at 0 to $4^{\circ} \mathrm{C}$ for $12 \mathrm{~h}$, and the inner solution was used as the elicitor preparation. This preparation contained a glycopeptide (molecular weight $>70 \mathrm{kDa}$ ) of which a sugar chain is glucose-mannose-mannose- $O$-serine (29). The lyophilized low-molecular-weight fraction was suspended in a small amount of distilled water, and fractionated by gel-filtration chromatography with a Toyopearl HW 40F column (Tosoh Co., Tokyo). Fractions suppressing the accumulation of pisatin were used as the suppressor preparation. In this report, we used the partially purified suppressor preparation including mucin-type glycopeptides, supprescins A and B (37), for measuring the overall effect of suppressor activity on $\mathrm{O}_{2}^{-}$generation in solubilized cell wall fractions of pea and cowpea. Concentrations of the elicitor and suppressor preparations were determined by the methods of Dubois et al.

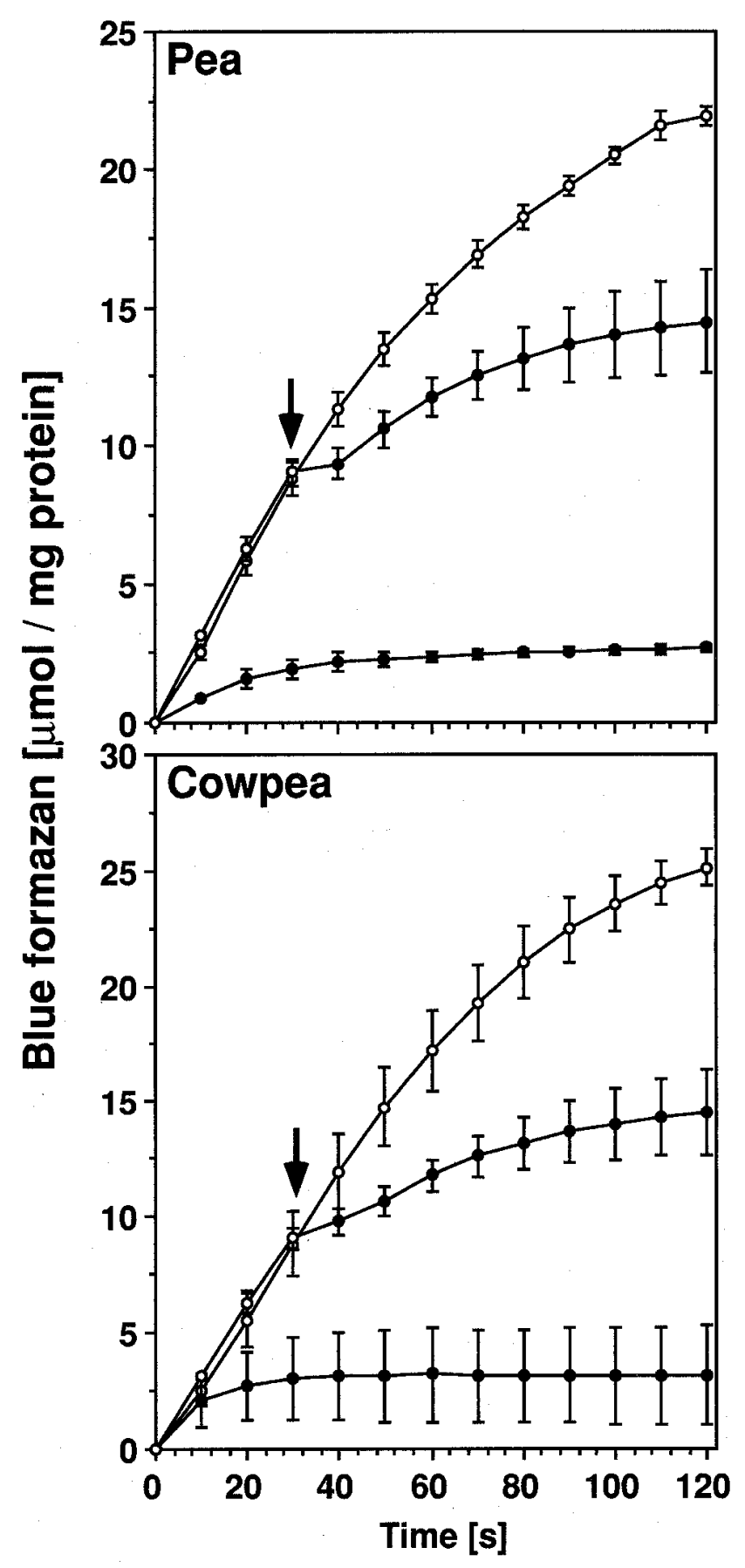

Fig. 1. Blue formazan formation in the fractions solubilized from cell walls of pea and cowpea. The assay was carried out in Tris-morpholineethanesulfonic acid ( $\mathrm{pH}$ 6.5) containing $20 \mathrm{mM} \mathrm{MnCl}_{2}, 2.5 \mu \mathrm{g} / \mathrm{ml}$ of nitroblue tetrazolium, $0.5 \mathrm{mM} \mathrm{NADH}$, and $0.5 \mathrm{mM} p$-coumaric acid in the absence $(\mathrm{O})$ or presence (-) of 100 units of superoxide dismutase (SOD). The blue formazan was determined by the method of Nathan et al. (30). Arrow heads indicated the addition of 100 units of SOD $30 \mathrm{~s}$ after the start of reaction. Each value represents the mean with standard deviation from triplicate experiments. 
(16) and Lowry et al. (26), with glucose and BSA as the standards, respectively.

Determination of $\mathrm{O}_{2}^{-}$generation. The $\mathrm{O}_{2}^{-}$generation via $\mathrm{NAD}(\mathrm{P}) \mathrm{H}$ oxidation in the solubilized cell wall fractions was measured by the method of Ishida et al. (22), with a slight modification. The assay mixture was composed of $30 \mathrm{mM}$ Tris-2- $(N-$ morpholino)ethanesulfonic acid (pH 6.5), $0.5 \mathrm{mM} \mathrm{NADH}, 20 \mathrm{mM}$ $\mathrm{MnCl}_{2}, 0.5 \mathrm{mM} p$-CA, $2.5 \mu \mathrm{g} / \mathrm{ml}$ of nitroblue tetrazolium, and 1.0 $\mu \mathrm{g}$ of solubilized cell wall fractions of pea and cowpea in the absence or presence of several inhibitors, catalase, and SOD, at $100 \mu \mathrm{g} / \mathrm{ml}$ of the elicitor or suppressor preparation of $M$. pinodes, alone or in combination. The reaction was started by the addition of $\mathrm{NAD}(\mathrm{P}) \mathrm{H}$, and the formation of blue formazan was monitored at $560 \mathrm{~nm}$ every $10 \mathrm{~s}$ for 2 min with a spectrophotometer (DU series 600; Beckman Instruments, Inc., Fullerton, $\mathrm{CA})$. The amount of blue formazan was determined by the method of Nathan et al. (30).

\section{RESULTS AND DISCUSSION}

It is reported that the systems for generation of $\mathrm{H}_{2} \mathrm{O}_{2}$ and $\mathrm{O}_{2}{ }^{-}$in the cell walls of horseradish and tobacco are involved in lignin synthesis $(19,20,27,28)$. However, the role of such a generation system in plant-microbe interactions is obscure. We also demonstrated that $\mathrm{O}_{2}^{-}$was generated in fractions solubilized from cell walls of pea and cowpea, since blue formazan formation, which was detectable in the fractions of both plants, was decreased by $90 \%$ in the presence of 100 units of SOD (Fig. 1). Moreover, formazan formation was also inhibited by the addition of SOD $30 \mathrm{~s}$ after the start of the reaction (Fig. 1).

As shown in Table 1, formazan formation in the solubilized cell wall fractions of pea and cowpea was markedly reduced in the absence of NADH. Because the activity in the absence of NADH was only restored to about $50 \%$ by the addition of the same molarity of NADPH, NADH was shown to be preferable to NADPH as the electron donor. The activity of NADH-dependent $\mathrm{O}_{2}^{-}$generation in the fractions solubilized from pea and cowpea cell walls was also markedly decreased in the absence of manganese ion or $p$-CA (Table 1). The formazan formation was also reduced in the presence of catalase, a scavenger of $\mathrm{H}_{2} \mathrm{O}_{2}$, in a dose-dependent manner (Fig. 2). These results showed that manganese ion, $p$-CA, and $\mathrm{H}_{2} \mathrm{O}_{2}$ were required for $\mathrm{O}_{2}^{-}$generation. Halliwell (20) showed that peroxidase-catalyzed $\mathrm{H}_{2} \mathrm{O}_{2} / \mathrm{O}_{2}{ }^{-}$generation depended on manganese ion and phenolic compounds, and was also accelerated by $\mathrm{H}_{2} \mathrm{O}_{2}$ during $\mathrm{NAD}(\mathrm{P}) \mathrm{H}$ oxidation. Thus, the requirement of these cofactors for $\mathrm{O}_{2}^{-}$generation and inhibition by catalase indicate that the $\mathrm{O}_{2}^{-}$generation in the fractions solubilized from pea and cowpea cell walls is dependent upon the activity of certain cell wall-bound peroxidase(s). The involvement of cell wall-bound peroxidase(s)

TABLE 1. Effect of manganese ion (Mn), $p$-coumaric acid ( $p$-CA), and $\mathrm{NAD}(\mathrm{P}) \mathrm{H}$ on blue formazan formation in the fractions solubilized from cell walls of pea and cowpea

\begin{tabular}{lrrrrr}
\hline & \multicolumn{2}{c}{ Pea } & & \multicolumn{2}{c}{ Cowpea } \\
\cline { 2 - 3 } \cline { 5 - 6 } & Blue formazan $^{\mathrm{a}}$ & $\%^{\mathrm{b}}$ & & Blue formazan $^{\mathrm{a}}$ & $\%^{\mathrm{b}}$ \\
\hline Complete $^{\mathrm{c}}$ & $14.31 \pm 2.70$ & 100 & & $20.90 \pm 1.89$ & 100 \\
-Mn & $5.46 \pm 0.34$ & 38 & & $8.93 \pm 1.56$ & 42 \\
$-p$-CA & $4.58 \pm 0.21$ & 32 & & $4.66 \pm 1.11$ & 22 \\
$-\mathrm{NADH}$ & $2.02 \pm 0.21$ & 14 & & $2.61 \pm 0.13$ & 12 \\
+NADPH $^{\mathrm{d}}$ & $5.82 \pm 0.88$ & 41 & & $11.66 \pm 0.36$ & 56 \\
\hline
\end{tabular}

${ }^{a}$ Blue formazan (micromoles per milligram of protein per minute) was determined at $25^{\circ} \mathrm{C}$ for $1 \mathrm{~min}$ by the method of Nathan et al. (30), and each value represents the mean with standard deviation from triplicate experiments.

${ }^{b}$ The percentage of the mean value is shown instead of that of the complete reaction mixture.

${ }^{\mathrm{c}}$ The complete reaction mixture was as described in Figure 1.

d NADPH was used as an electron donor, instead of NADH, in the complete reaction mixture. in $\mathrm{O}_{2}^{-}$generation is also supported by additional results. Inhibitors of NADPH oxidase, quinacrine and DPI, that bind to flavoproteins (11) did not inhibit $\mathrm{O}_{2}^{-}$generation in the solubilized cell wall fractions of pea and cowpea. Other inhibitors of NADPH oxidase, imidazole and pyridine, that bind to $b$-type cytochromes (21) also scarcely affected $\mathrm{O}_{2}^{-}$generation in the solubilized cell wall fractions of both plant species (Table 2). On the other hand, SHAM, an inhibitor of peroxidase (2), markedly inhibited the $\mathrm{O}_{2}^{-}$generation in fractions of both plants (Table 2). Taken together with the

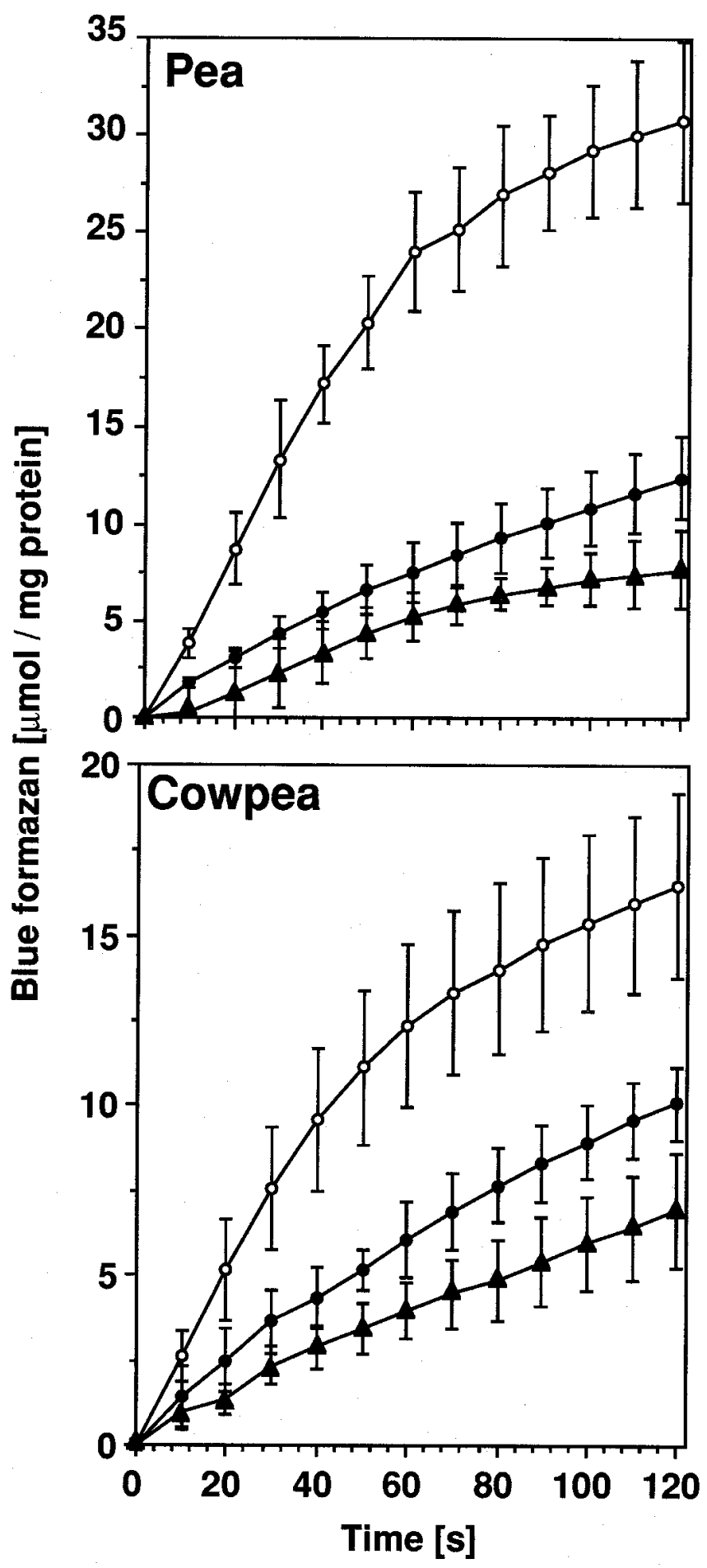

Fig. 2. Effect of catalase on blue formazan formation in the fractions solubilized from cell wall fractions of pea and cowpea. The assay was carried out in the reaction mixture as described in Figure 1 in the absence $(O ; 0$ unit) or presence of 50 units $(\bullet)$ or 100 units of catalase $(\boldsymbol{\Delta})$. Each value represents the mean with standard deviation from triplicate experiments. 
data in Table 1, these data support the hypothesis that certain cell wall-bound peroxidase(s) participate in the NADH-dependent $\mathrm{O}_{2}{ }^{-}$ generation in these cell wall fractions.

Several reports showed that cell wall-bound peroxidase participated in generation of $\mathrm{H}_{2} \mathrm{O}_{2}$ and $\mathrm{O}_{2}^{-}(19,20,27,28)$. However, it has not been clarified whether electron donors such as $\mathrm{NAD}(\mathrm{P}) \mathrm{H}$ exist in extracellular spaces or not. Recently, it was reported that NAD was contained in intercellular fluid (34), and cell wall-bound malate dehydrogenase has been reported to exist $(17,18)$. The fractions solubilized from pea and cowpea cell walls also contained the activity of malate dehydrogenase (A. Kiba, K. Toyoda, Y. Ichinose, T. Yamada, and T. Shiraishi, unpublished data). Taken together with these results, cell wall-bound malate dehydrogenase might act as a supplier for electron donors. Another study reported that apoplastic fluid aspirated from cell walls of elicited-French bean cells contained an, as yet, unidentified reductant (4). This result suggested that electron donors might be either secreted into cell walls or produced in response to elicitors.

Our previous reports showed that ATPase activity and polyphosphoinositide metabolism are involved in recognition and signal transduction leading to induction of defense responses in pea plants $(41,42,48)$. Orthovanadate, an inhibitor of P-type ATPase, prevented the accumulation of pisatin (47) and mRNAs encoding phenylalanine ammonia-lyase and chalcone synthase (46), key enzymes in the pisatin biosynthetic pathway, in a manner similar to the $M$. pinodes-suppressor (44). An inhibitor of phospholipase C, neomycin, also blocked the defense responses of pea (42). Moreover, neomycin induced susceptibility of pea cells even to avirulent pathogens (41). Based on these findings, we investigated the effects of inhibitors of ATPase and phospholipase C on the blue formazan formation in fractions solubilized from pea and cowpea cell walls. Though neomycin did not affect $\mathrm{O}_{2}^{-}$generation in either fraction, orthovanadate markedly inhibited the activity of the fractions from both plants (Table 2). The results are similar to those with cell wall-bound ATPases. That is, the cell wall-bound ATPase was inhibited by orthovanadate, but not by neomycin (25), whereas the plasma membrane ATPases were inhibited by both inhibitors (48). Thus, it is possible that the $\mathrm{O}_{2}^{-}$generation in solubilized cell wall fractions from pea and cowpea might be associated with cell wall-bound ATPases. However, since it has been shown that vanadate acts as an inhibitor of peroxidase (33), it is currently unknown whether the inhibition of $\mathrm{O}_{2}^{-}$generation by orthovanadate resulted from the inhibition of cell wall-bound peroxidase or ATPase.

The elicitor preparation from $M$. pinodes enhanced nonspecifically the blue formazan formation in the fractions from both pea

TABLE 2. Effects of several inhibitors on blue formazan formation in the fractions solubilized from cell walls of pea and cowpea

\begin{tabular}{lrrrrr}
\hline & \multicolumn{2}{c}{ Pea } & & \multicolumn{2}{c}{ Cowpea } \\
\cline { 2 - 3 } \cline { 5 - 6 } & \multicolumn{1}{c}{$\begin{array}{c}\text { Blue } \\
\text { formazan }\end{array}$} & $\%^{\mathrm{b}}$ & & $\begin{array}{c}\text { Blue } \\
\text { formazan }\end{array}$ & $\%^{\mathrm{b}}$ \\
\hline Water control & $19.07 \pm 0.74$ & 100 & & $19.39 \pm 0.65$ & 100 \\
+ $\mathrm{Na}_{3} \mathrm{VO}_{4}$ & $8.68 \pm 0.75$ & 46 & & $2.90 \pm 0.47$ & 15 \\
+Neomycin & $19.18 \pm 1.16$ & 101 & & $19.38 \pm 1.73$ & 100 \\
+Imidazole & $17.39 \pm 0.81$ & 91 & & $21.08 \pm 1.32$ & 108 \\
+Pyridine & $21.18 \pm 0.55$ & 111 & & $18.96 \pm 0.66$ & 98 \\
+Diphenyleneiodonium & $17.52 \pm 0.69$ & 92 & & $18.29 \pm 0.76$ & 94 \\
+Quinacrine & $20.44 \pm 0.68$ & 107 & & $22.73 \pm 1.15$ & 117 \\
+Salicylhydroxamic acid & $6.78 \pm 0.36$ & 36 & & $8.43 \pm 0.35$ & 43 \\
\hline
\end{tabular}

a The assay was carried out at $25^{\circ} \mathrm{C}$ for $1 \mathrm{~min}$ in the reaction mixture, as described in Figure 1, in the absence or presence of $1 \mathrm{mM} \mathrm{Na}_{3} \mathrm{VO}_{4}, 1 \mathrm{mM}$ neomycin, $10 \mathrm{mM}$ imidazole, $20 \mathrm{mM}$ pyridine, $25 \mu \mathrm{M}$ diphenyleneiodonium, $0.5 \mathrm{mM}$ quinacrine, or $5 \mathrm{mM}$ salicylhydroxamic acid. The amount of formed formazan (micromoles per milligram of protein per minute) was determined by the method of Nathan et al. (30).

b The percentage of the mean value is shown instead of that of the water control.

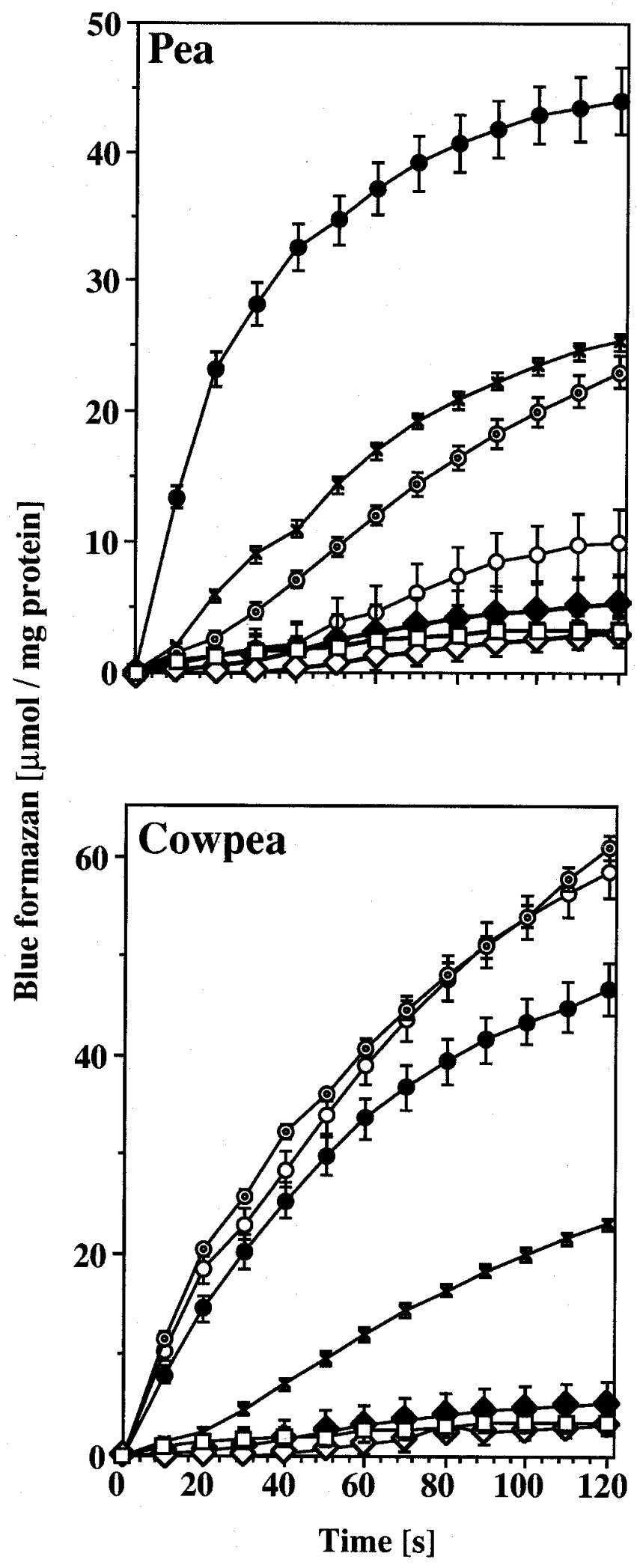

Fig. 3. Time course study and effects of the elicitor and suppressor from Mycosphaerella pinodes on blue formazan formation in the fractions solubilized from cell walls of pea and cowpea. The assay was carried out at $25^{\circ} \mathrm{C}$ for $2 \mathrm{~min}$ in Tris-morpholineethanesulfonic acid ( $\mathrm{pH} 6.5$ ) containing $20 \mathrm{mM} \mathrm{MnCl}_{2}, 2.5 \mu \mathrm{g} / \mathrm{ml}$ of nitroblue tetrazolium, $0.5 \mathrm{mM} \mathrm{NADH}$, and $0.5 \mathrm{mM}$-coumaric acid in the absence ( $\mathrm{X}$; water control) or presence of 100 units of superoxide dismutase (SOD) $(\diamond), 100 \mu \mathrm{g} / \mathrm{ml}$ of elicitor alone $(\bullet), 100 \mu \mathrm{g} / \mathrm{ml}$ of suppressor alone $(\bigcirc)$, elicitor plus suppressor $(\odot)$, elicitor plus SOD $(\diamond)$, and suppressor plus SOD ( $\square)$. The blue formazan was determined by the method of Nathan et al. (30). Each value represents the mean with standard deviation from triplicate experiments. 
and cowpea in a dose-dependent manner (Figs. 3 and 4). On the other hand, the suppressor preparation from $M$. pinodes inhibited blue formazan formation in the pea fraction in a dose-dependent manner (Figs. 3 and 4), and even the concomitant presence of the suppressor with the elicitor decreased the blue formazan formation in the pea fraction to the level of the water control (Fig. 3). On the other hand, the suppressor preparation did not inhibited elicitor-enhanced blue formazan formation in the cowpea fraction (Fig. 3). Moreover, the blue formazan formation in the cowpea fraction was not inhibited, but was rather enhanced by the suppressor alone in a dose-dependent manner (Fig. 4). The elicitor and suppressor preparations from $M$. pinodes did not contain the activity to form blue formazan by themselves (data not shown).

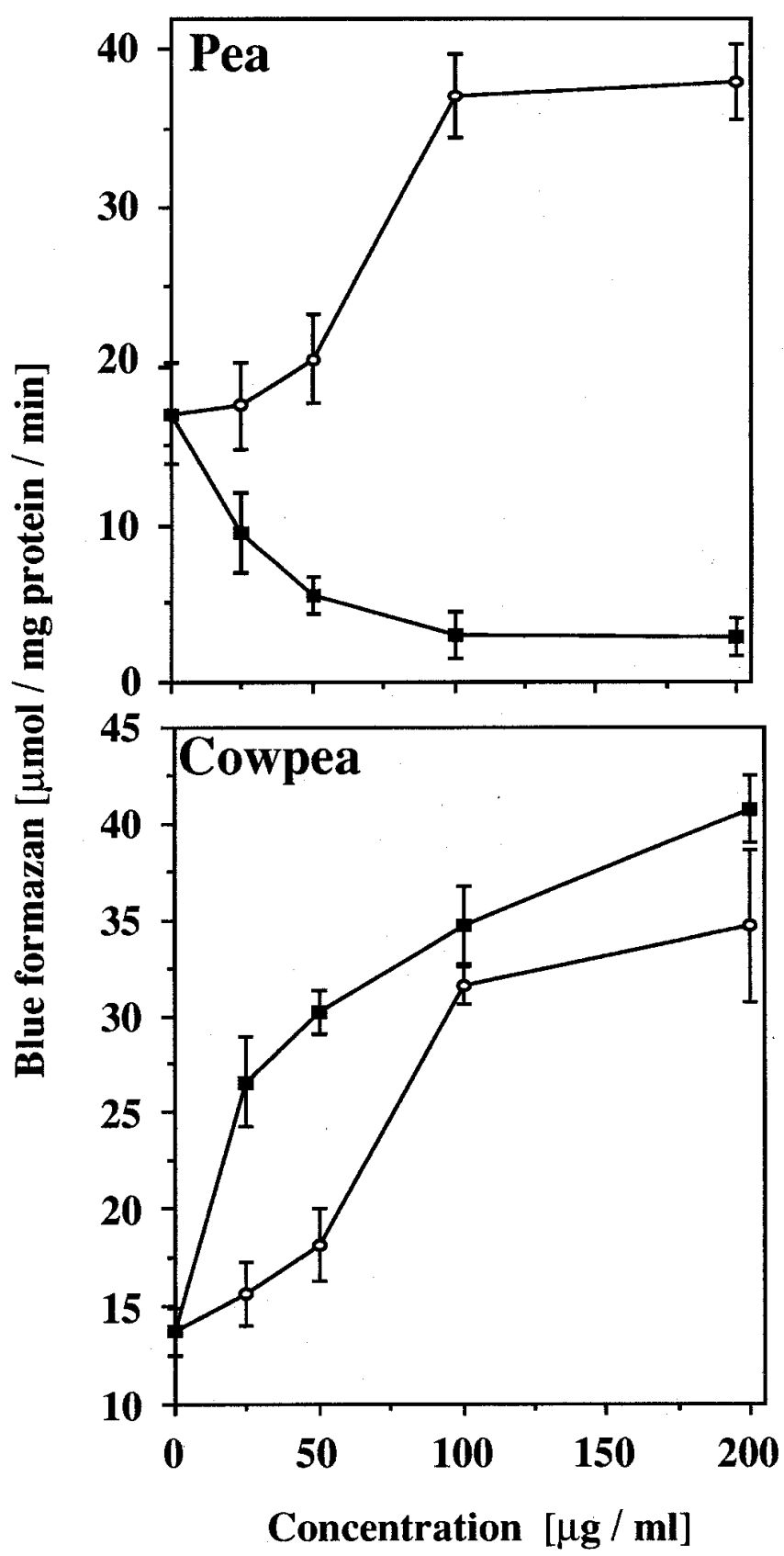

Fig. 4. Effects of the elicitor and suppressor preparations from $M y$ cosphaerella pinodes on blue formazan formation in the fractions solubilized from cell walls of pea and cowpea. The assay was carried out as described in Figure 1 in the absence $(0 \mu \mathrm{g} / \mathrm{ml})$ or presence of several concentrations of elicitor $(O)$ or suppressor $(\mathbf{\square})$. Each value represents the mean with standard deviation from triplicate experiments.
These results showed that $\mathrm{O}_{2}^{-}$generation in the solubilized cell wall fractions is regulated by these fungal signal molecule preparations, and, especially, that the suppressor acts on the activity in a species-specific manner.

Though $\mathrm{O}_{2}^{-}$generation in the solubilized cell wall fractions is regulated by these fungal signal molecule preparations, as described above, it has been obscured how $\mathrm{O}_{2}^{-}$generated in the cell wall participates in plant-pathogen interactions. Bolwell (4) and Bolwell et al. (5) reported that cell wall-bound peroxidase participated in production of $\mathrm{H}_{2} \mathrm{O}_{2}$ in suspension-cultured cells of French bean in response to the elicitor. On the other hand, we recently found that the elicitor preparation from $M$. pinodes induced $\mathrm{O}_{2}^{-}$ generation on the surfaces of pea and cowpea leaves, and that the $\mathrm{O}_{2}{ }^{-}$generation was affected by the suppressor preparation from its fungus in a species-specific manner (23). The $\mathrm{O}_{2}^{-}$generation on the leaf surfaces of both plants induced by the elicitor preparation was markedly inhibited by an inhibitor of peroxidase, SHAM, not by inhibitors of NADPH oxidase, imidazole and quinacrine (23). Since these properties of $\mathrm{O}_{2}^{-}$generation on the leaf surfaces of pea and cowpea strictly coincide with those in the fractions solubilized from pea and cowpea cell walls, cell wall-bound peroxidase from pea and cowpea might act as the supplier for $\mathrm{O}_{2}^{-}$generation on the surfaces of pea and cowpea leaves.

The suppressor from $M$. pinodes was proposed to be a determinant of host-parasite specificity, since it inhibited defense responses and induced susceptibility in only host plants of $M$. pinodes (32, $38,46)$. One of the major effects of the suppressor was thought to be inhibition of ATPase activity of the host plant. Cytochemical observation showed that the suppressor specifically inhibited the ATPase activity of pea, but not those of the nonhost plant species barley, cowpea, kidney bean, and soybean, whereas ATPase activities in plasma membranes isolated from these five plant species were nonspecifically inhibited by the suppressor (35). On the other hand, the cell wall-bound ATPases were regulated even in vitro by the suppressor in a species-specific manner $(24,25)$. Thus, the cell wall-bound ATPase was thought to be tightly correlated to defense responses and determination of host-parasite specificity. In our current results, NADH-dependent $\mathrm{O}_{2}^{-}$generation, which may be mediated by cell wall bound-peroxidase(s), was also regulated by the suppressor in a species-specific manner (Figs. 3 and 4). These results suggest the possibility that the activity of cell wall-bound ATPase is tightly correlated with NADH-dependent $\mathrm{O}_{2}^{-}$generation by peroxidase(s). In fact, we recently found that the cell wall-bound ATPases of pea and cowpea were copurified by affinity chromatography with an ATP-conjugate agarose column with peroxidase(s) activity (A. Kiba, K. Toyoda, Y. Ichinose, T. Yamada, and T. Shiraishi, unpublished data).

It has been thought that plant cell walls play an important role in plant defense responses, such as acting as a physical barrier against invasion by potent pathogens. Insolubilization of pre-existent protein $(7,8)$ or lignification $(43)$ rapidly induced by inoculation with pathogens or by treatment with elicitors seems to strengthen cell walls. Another report showed that polygalacturonaseinhibiting proteins in cell walls may contribute to the formation of elicitor-active oligogalacturonide fragments (9). Thus, plant cell walls act as not only physical barriers, but also as a site for generating second messengers for defense responses. Together with our previous reports $(24,25)$, our current data show that plant cell walls alone are able to recognize and respond to fungal signals, since cell wall-bound ATPase(s) and the $\mathrm{O}_{2}^{-}$generation system are nonspecifically stimulated by the $M$. pinodes-elicitor, but are affected by the $M$. pinodes-suppressor in a speciesspecific manner. We, therefore, present the hypothesis that cell walls might play a crucial role in recognition of fungal signal molecules, regulation of defense responses, and determination of plants-pathogens specificity.

Further experiments are needed to elucidate not only the relationship between the receptors for these fungal signals and the 
regulatory systems for $\mathrm{O}_{2}^{-}$generation in cell walls, but also the role of $\mathrm{O}_{2}^{-}$in signal transduction leading to the defense responses of plants.

\section{ACKNOWLEDGMENTS}

This research was supported, in part, by a Grant-in-Aid for Scientific Research from the Ministry of Education, Science, and Culture of Japan and by a grant from the Japan Society for the Promotion of Science (JSPS-RFTF96L00603). We thank Sankyo Co., Ltd., Tokyo, for their financial support. We also thank R. L. Nicholson for assistance in the preparation of this manuscript.

\section{LITERATURE CITED}

1. Askerlund, P. C., Larsson, C., Widell, S., and Moller, I. M. 1987. $\mathrm{NAD}(\mathrm{P}) \mathrm{H}$ oxidase and peroxidase activities in purified plasma membranes from cauliflower inflorescences. Plant Physiol. 71:9-19.

2. Auh, C. K., and Murphy, T. 1995. Plasma membrane redox enzyme is involved in the synthesis of $\mathrm{O}_{2}^{-}$and $\mathrm{H}_{2} \mathrm{O}_{2}$ by Phytophthora elicitorstimulated rose cells. Plant Physiol. 107:1214-1247.

3. Baker, C. J., and Orlandi, E. W. 1995. Active oxygen in plant pathogenesis. Annu. Rev. Phytopathol. 33:299-321.

4. Bolwell, G. P. 1996. The origin of the oxidative burst in plants. Biochem. Soc. Transact. 24:438-441.

5. Bolwell, G. P., Butt, V., Davies, D., and Zimmerlin, A. 1995. The origin of the oxidative burst in plants. Free Radical Res. 23:517-532.

6. Bradford, M. M. 1976. A rapid and sensitive method for quantitation of microgram quantities of protein utilizing the principle of protein-dye binding. Anal. Biochem. 72:248-254.

7. Bradly, D., Kjellbom, P., and Lamb, C. J. 1992. Elicitor- and woundinduced oxidative cross-linking of a proline-rich plant cell wall protein: A novel rapid defense response. Cell 70:21-30.

8. Brisson, L. F., Tenhaken, R., and Lamb, C. 1994. Function of oxidative cross-linking of cell wall structural proteins in plant disease resistance. Plant Cell 6:1703-1712.

9. Cervone, F., Harn, M. G., Lorenzo, G. D., Darvill, A., and Albersheim, P. 1989. Host-pathogen interaction XXXIII. A plant protein converts a fungal pathogenesis factor into an elicitor of plant defense responses. Plant Physiol. 90:542-548.

10. Chen, Z., Silva, H., and Klessig, D. F. 1993. Active oxygen species in the induction of plant systemic acquired resistance by salicylic acid. Science 262:1883-1885.

11. Cross, A. R., and Jones, O. T. G. 1991. Enzymic mechanisms of superoxide production. Biochim. Biophys. Acta 1075:281-298.

12. Doke, N. 1983. Involvement of superoxide anion generation in the hypersensitive response of potato tuber tissues to infection with an incompatible race of Phytophthora infestans and to the hyphal wall components. Physiol. Plant Pathol. 23:345-357.

13. Doke, N. 1983. Generation of superoxide anion by potato tuber protoplasts during the hypersensitive response to hyphal wall components of Phytophthora infestans and specific inhibition of the reaction by suppressors of hypersensitivity. Physiol. Plant Pathol. 23:359-367.

14. Doke, N., and Chai, B. 1985. Activation of superoxide generation and enhancement of resistance against compatible races of Phytophthora infestans in potato plants treated with digitonin. Physiol. Plant Pathol. 27: 323-334.

15. Doke, N., and Miura, Y. 1995. In vitro activation of NADPH-dependent $\mathrm{O}_{2}^{-}$generating system in a plasma membrane-rich fraction of potato tuber tissue by treatment with an elicitor from Phytophthora infestans or with digitonin. Physiol. Mol. Plant Pathol. 46:17-28.

16. Dubois, S. M., Gilles, K. A., Hamilton, J. K., Rebers, P. A., and Smith, F. 1956. Colorimetric method for determination of sugars and related substance. Anal. Chem. 28:350-356.

17. Frehner, M., and Conn, E. E. 1987. The linamarin $\beta$-glucosidase in costarican wild lima beans (Phaseolus lunatus L.) is apoplastic. Plant Physiol. 84:1296-1300.

18. Gross, G. G. 1977. Cell wall-bound malate dehydrogenase from horseradish. Phytochemistry 16:319-321.

19. Gross, G. G., Janse, C., and Elstner, E. F. 1977. Involvement of malate, monophenols, and hydrogen peroxide formation by isolated cell walls from horseradish (Armoracia lapathifolia Gilib.). Planta 136:271-276.

20. Halliwell, B. 1978. Lignin synthesis: The generation of hydrogen peroxide and superoxide by horseradish peroxidase and its stimulation by manganese(II) and phenols. Planta 140:81-88.

21. Iizuka, T., Kanegasaki, S., Makino, R., Tanaka, T., and Ishimura, Y. 1985. Pyridine and imidazole reversibly inhibit the respiratory burst in porcine and human neutrophils: Evidence for the involvement of cytochrome $b 588$ in the reaction. Biochem. Biophys. Res. Commun. 130:621-626.

22. Ishida, A., Ookubo, K., and Ono, K. 1987. Formation of hydrogen peroxide by $\mathrm{NAD}(\mathrm{P}) \mathrm{H}$ oxidation with isolated cell wall-associated peroxidase from cultured liverwort cells, Marchantia polymorpha L. Plant Cell Physiol. 28:723-726.

23. Kiba, A., Toyoda, K., Ichinose, Y., Yamada, T., and Shiraishi, T. 1996. Species-specific suppression of superoxide-anion generation on surface of pea leaves by the suppressor from Mycosphaerella pinodes. Ann. Phytopathol. Soc. Jpn. 62:508-512.

24. Kiba, A., Toyoda, K., Ichinose, Y., Yamada, T., and Shiraishi, T. 1996. Specific response of partially purified cell wall-bound ATPases to fungal suppressor. Plant Cell Physiol. 37:207-214.

25. Kiba, A., Toyoda, K., Yamada, T., Ichinose, Y., and Shiraishi, T. 1995. Specific inhibition of cell wall-bound ATPases by fungal suppressor from Mycosphaerella pinodes. Plant Cell Physiol. 36:809-817.

26. Lowry, O. H., Rosebrough, N. J., Farr, A., and Randall, R. J. 1951. Protein measurement with the Folin reagent. J. Biol. Chem. 193:265-275.

27. Mader, M., and Amberg-Ficher, V. 1982. Role of peroxidase in lignification of tobacco cells. Plant Physiol. 70:1128-1131.

28. Mader, M., and Fussl, R. 1982. Role of peroxidase in lignification of tobacco cells. II. Regulation by phenolic compounds. Plant Physiol. 70: $1132-1134$.

29. Matsubara, M., and Kuroda, H. 1987. The structure and physiological activity of glycoprotein secreted from conidia of Mycosphaerella pinodes II. Chem. Pharm. Bull. 35:249-255.

30. Nathan, D. G., Baehner, R. L., and Weaver, D. K. 1969. Failure of nitroblue tetrazolium reduction in the phagocytic vacuoles of leukocytes in chronic granulomatous disease. J. Clin. Invest. 48:1895-1904.

31. Oku, H., Shiraishi, T., and Ouchi, S. 1977. Suppression of induction of phytoalexin, pisatin by low-molecular-weight substances from spore germination fluid of pea pathogen, Mycosphaerella pinodes. Naturwissenschaften 64:643.

32. Oku, H., Shiraishi, T., Ouchi, S., Ishiura, M., and Matueda, R. 1980. A new determinant of pathogenicity in plant disease. Naturwissenschaften 67:310.

33. Serra, M. A., Sabbioni, E., Marchesini, A., Pintar, A., and Valott, M. 1990. Vanadate as an inhibitor of plant and mammalian peroxidases. Biol. Trace Elem. Res. 23:151-164.

34. Shinkle, J. R., Swoap, S. J., and Jones, R. 1992. Cell wall free space of Cucumis hypocotyls contains NAD and a blue light-regulated peroxidase activity. Plant Physiol. 98:1336-1341.

35. Shiraishi, T., Araki, M., Yoshioka, H., Kobayashi, I., Yamada, T., Ichinose, Y., Kunoh, H., and Oku, H. 1991. Inhibition of ATPase activity in plasma membranes in situ by a suppressor from a pea pathogen, $M y$ cosphaerella pinodes. Plant Cell Physiol. 32:1067-1075.

36. Shiraishi, T., Oku, H., Yamashita, M., and Ouchi, S. 1978. Elicitor and suppressor of pisatin induction in spore germination fluid of pea pathogen, Mycosphaerella pinodes. Ann. Phytopathol. Soc. Jpn. 44:659-665.

37. Shiraishi, T., Saitoh, K., Kim, H. M., Kato, T., Tahara, M., Oku, H., Yamada, T., and Ichinose, Y. 1992. Two suppressors, supprescins A and B, secreted by a pea pathogen, Mycosphaerella pinodes. Plant Cell Physiol. 33:663-667.

38. Shiraishi, T., Yamada, T., Oku, H., and Yoshioka, H. 1991. Suppressor production as a key factor for fungal pathogenesis. Pages 151-162 in: Molecular Strategies of Pathogens and Host Plants. S. S. Patil, S. Ouchi, D. Mills, and C. Vance, eds. Springer-Verlag, New York.

39. Shiraishi, T., Yamada, T., Saitoh, K., Kato, T., Toyoda, K., Yoshioka, H., Kim, H. M., Ichinose, Y., Tahara, M., and Oku, H. 1994. Suppressor: Determinants of specificity produced by plant pathogens. Plant Cell Physiol. 35:1107-1119.

40. Thanutong, P., Oku, H., Shiraishi, T., and Ouchi, S. 1982. Isolation and partial characterization of an elicitor of pisatin production from spore germination fluid of pea pathogen, Mycosphaerella pinodes. Sci. Rep. Fac. Agric. Okayama Univ. 59:1-9.

41. Toyoda, K., Shiraishi, T., Yoshioka, T., Ichinose, Y., and Oku, H. 1993. Rapid changes in polyphosphoinositide metabolism in pea in response to fungal signals. Plant Cell Physiol. 34:729-735.

42. Toyoda, K., Shiraishi, T., Yoshioka, H., Yamada., T., Ichinose, Y., and Oku, H. 1992. Regulation of polyphosphoinositide metabolism in pea plasma membrane by elicitor and suppressor from a pea pathogen, $M y$ cosphaerella pinodes. Plant Cell Physiol. 33:445-452.

43. Vance, C. P., Kink, I. K., and Sherwood, R. T. 1980. Lignification as a mechanism of disease resistance. Annu. Rev. Phytopathol. 18: 259-288.

44. Yamada, T., Hashimoto, H., Shiraishi, T., and Oku, H. 1989. Suppression of pisatin, phenylalanine ammonia-lyase mRNA, and chalcone synthase mRNA accumulation by putative pathogenicity factor 
from the fungus Mycosphaerella pinodes. Mol. Plant-Microbe Interact. 2:256-261.

45. Yamamoto, Y., Oku, H., Shiraishi, T., Ouchi, S., and Koshizawa, K. 1986. Non-specific induction of pisatin and local resistance in pea leaves by elicitor from Mycosphaerella pinodes, M. melonis and $M$. ligulicola and effect of suppressor from M. pinodes. J. Phytopathol. 117:136-143.

46. Yoshioka, H., Shiraishi, T., Kawamata, S., Nasu, K., Yamada, T., Ichinose, Y., and Oku, H. 1992. Orthovanadate suppresses accumulation of phenylalanine ammonia-lyase mRNA and chalcone synthase mRNA in pea epicotyls induced by elicitor from Mycosphaerella pinodes. Plant Cell Physiol. 33:201-204.

47. Yoshioka, H., Shiraishi, T., Nasu, K., Yamada, T., Ichinose, Y., and Oku, H. 1992. Suppression of activation of chitinase and $\beta-1,3$-glucanase in pea epicotyls by orthovanadate and suppressor from Mycosphaerella pinodes. Ann. Phytopathol. Soc. Jpn. 58:405-410.

48. Yoshioka, H., Shiraishi, T., Yamada, T., Ichinose, Y., and Oku, H. 1990. Suppression of pisatin production and ATPase activity in pea plasma membranes by orthovanadate, verapamil and a suppressor from $M y$ cosphaerella pinodes. Plant Cell Physiol. 31:1139-1146. 